\title{
The Eggs and Larvæ of Philbertia gracilis (Montagu).
}

\author{
By \\ Marie V. Lebour, D.Sc., \\ Naturalist at the Plymouth Laboratory.
}

With Plate 1.

THe genus Philbertia, belonging to the family Turridæ, is well known to have the larval shell beautifully sculptured and, as it is retained as the apex of the adult shell instead of being knocked off or concealed as is the case with many gastropods, it is easy to identify as belonging to this group, the veligers also reaching a large size and being conspicuous in the plankton.

Philbertia (Comarmondia) gracilis is fairly common in the Plymouth waters from 20-35 fathoms, usually in muddy ground, sometimes living with Turritella. Crawshay found one living from 40-42 fathoms S.W. of the Eddystone (see Plymouth Marine Fauna, 1931, Marine Biological Association). Its larvæ are quite common in small numbers in the plankton from inside and outside the Sound, usually outside, in spring and summer, the greatest number in the summer. It is one of the largest of the planktonic larval molluses, reaching a length of $1.76 \mathrm{~mm}$. or even more, and must stay for a long time in the plankton.

Jeffreys (1867) describes the apical whorls of this species (as Defrancia gracilis), although his description does not agree exactly with the Plymouth specimen, as he says that the top whorls are reticulated whereas they are really dotted and striated.

In the summer of 1931 two adult shells were placed in a plunger-jar where they lived quite comfortably, eating the deposits on the sides and bottom. In March of the following year seven capsules were laid on the side of the glass. Later, in April, another specimen was placed in the same jar which also laid several capsules of eggs. The eggs have not been seen before, and they and the larvæ are described here for the first time.

The capsules are very characteristic (Plate 1, Figs. 1-2), thick walled but fairly transparent, measuring $3.4 \mathrm{~mm}$. across, the height about onefifth of the diameter. The lower surface, attached to the glass, is flat, the upper raised portion reticulated with an irregular mesh raised into spiny processes. At the top is an oval depression covered by a much thinner skin through which the larvæ emerge. Each capsule contains about 
PLATE 1.

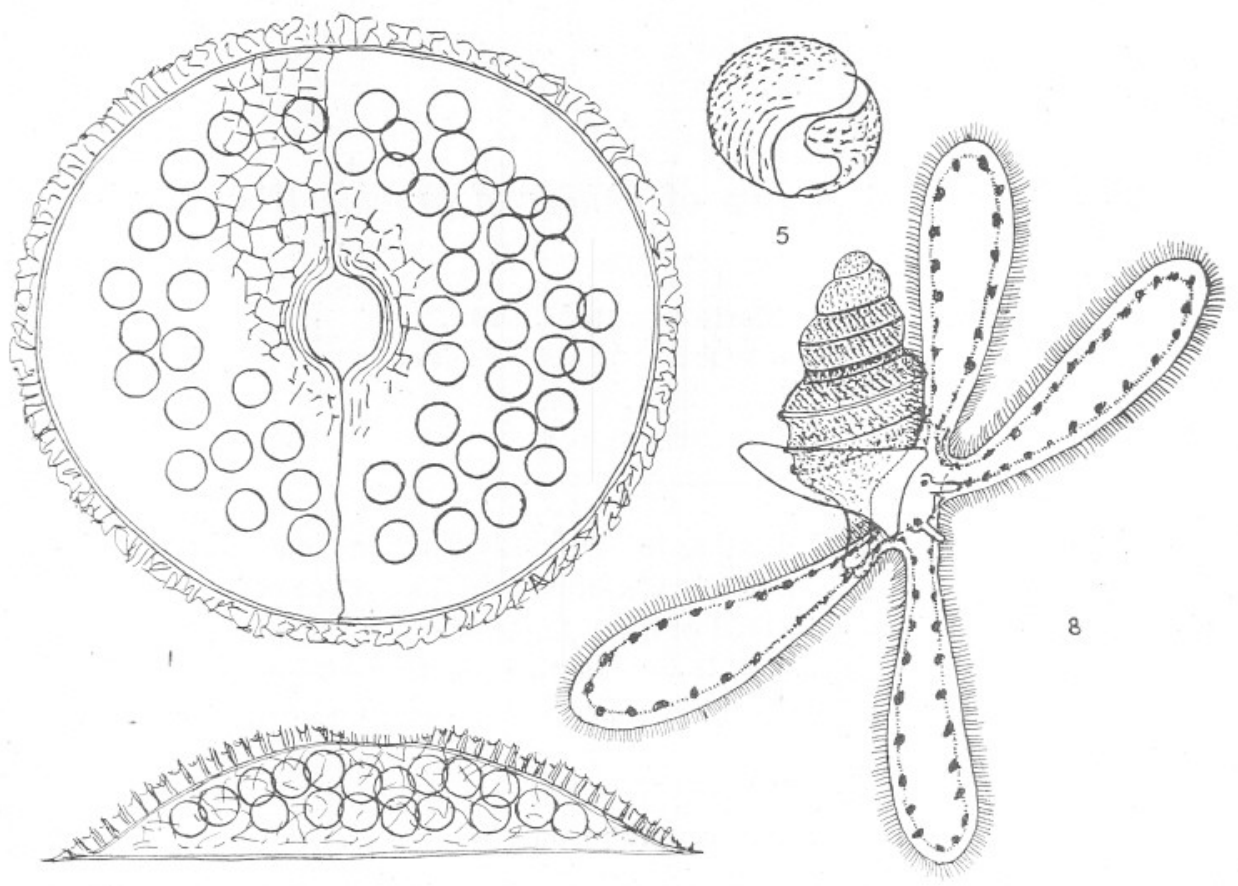

2

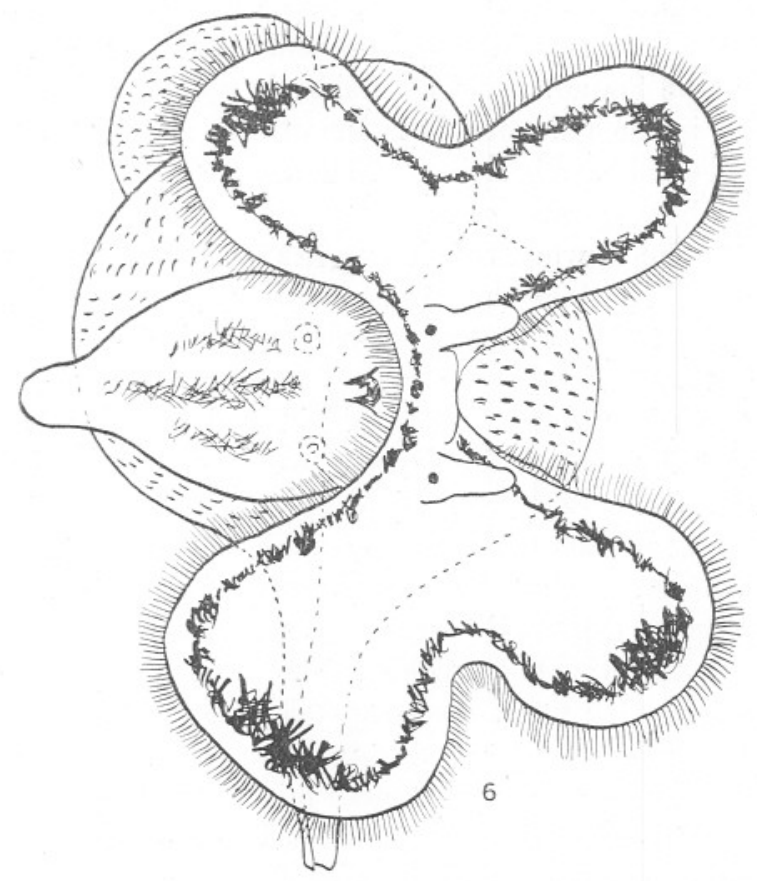

$\int(5)$ (n)

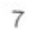

4

3

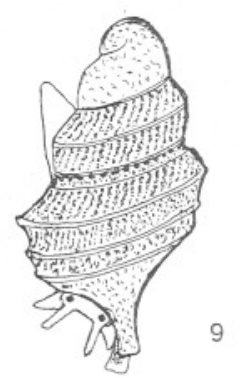


50 eggs, each egg measuring about $0 \cdot 16 \mathrm{~mm}$. across. The eggs take a long time to develop and many are devoured by the others, about six to twelve larvæ remaining to grow into veligers. The earliest eggs (17.3.32) did not develop into veligers for several weeks (Plate 1, Fig. 3), and when they were ready to hatch (29.4.32) they did not live. An unusual feature of these veligers is that the velum is provided with conspicuous brown pigment some time before the larva emerges from the capsule. The veligers are moving about for many days inside. This was the case in all those in the plunger-jars. No egg capsules were seen under natural conditions. The velum is slightly bilobed and attain a large size before hatching.

The shell of the newly hatched larva from the egg measures about $0 \cdot 24 \mathrm{~mm}$. across with a brown horn-coloured shell, sculptured with irregular dots and flecks (Plate 1, Figs. 4-5). The mouth is drawn out slightly to form the beginning of a canal and the outer lip drawn out and inflected to form a supporting central tooth with a hollow each side for support of the velum. The velum extends for some way beyond the shell, measuring about $0.60 \mathrm{~mm}$. across, each lobe being indented in the centre so that there is an indication of four lobes, and there is a large amount of brown pigment forming a border and masses of dark brown at the corners. The cilia surround the velum in the usual manner, the upper and lower rows on ridges forming a groove to the mouth. In front of the eyes there is a broad lobe, the tentacles are short and otocysts conspicuous. The short foot is rounded and slightly drawn out behind and the operculum large. The mouth shows in front of the foot. Young similar to this can be found in the plankton, usually in early summer and late spring, and stages up to the late veligers ready to metamorphose in summer and early autumn.

The canal grows quickly and shells with only two to two and a half whorls have a very long one (Plate 1, Figs. 6-7). At this stage the shell

\section{EXPLANATION OF PLATE 1.}

Philbertia (Comarmondia) gracilis.

(Scale B is six times the scale of A. Figs. 1-4, 7-9 Scale A, Figs. 5, 6 Scale B.)

FrG. 1.-Egg capsule seen from above, laid on glass of plunger-jar, $3 \cdot 4 \mathrm{~mm}$. across.

FIG. 2.-The same, side view.

Fig. 3.-Larva from inside the capsule, nearly ready to hatch.

Fig. 4.-Newly hatched larva.

FrG. 5.-Shell of newly hatched larva from plankton.

Frg. 6.-Young larva, rather older, from plankton, shell $0.80 \mathrm{~mm}$. long.

FIG. 7.-Shell of same.

FIG. 8.-Larva nearly ready to metamorphose from plankton.

FIG. 9.-Larva metamorphosed in plunger-jar, $1.76 \mathrm{~mm}$. long. 
measures about $0.80 \mathrm{~mm}$. long, the velum having a brownish tinge, the sides still more indented and the brown border more conspicuous but not. yet broken up into definite spots. The tentacles are longer and the foot more drawn out with grey pigment on the sole. The shell is still flecked, but with a definite pattern on the second whorl. Later larvæ show a gradual lengthening of the velar lobes and large orange and brown spots. are scattered irregularly along the border, the velum itself being brown, the rest of the animal yellowish. The third and fourth whorls of the shell are keeled and sculptured with conspicuous oblique striations (Plate 1, Fig. 8). The canal is now not so long compared with the shell and contains the siphon which in the latest stages is dotted with bright pink as it is in the adult. When the shell measures about $1.76 \mathrm{~mm}$. in length and the velar lobes are very long, projecting well beyond the shell, the veliger is at its largest and will soon metamorphose. The sculpture of the shell is very characteristic, the apex dotted and flecked for about one and a half whorls, the next whorl keeled with oblique irregular striæ formed of dots above and below the keel, the last whorl with three keels with oblique dots and striæ. Below the suture is a row of regular dots and the two last. whorls. The velar lobes are very long and narrow, bordered with regular dark brown and orange spots at intervals; the foot is somewhat pointed behind and drawn out anteriorly at the sides covering the mouth; the tentacles are rather short. The animal can now either swim or crawl, and very soon loses the velum. Late larvæ were kept in plunger-jars until the velum disappeared (Plate 1, Fig. 9).

This late larva is a beautiful little object and quite easy to see with the naked eye. When swimming the shell is below, the velum above with the long lobes outstretched or sometimes curving over the shell. It is one of the larvæ most often seen in the summer plankton at Plymouth and must. stay for a long time as a veliger.

\section{LITERATURE.}

Jeffreys, G. 1867. British Conchology, Vol. IV. 